Kong. Res. J. 1(2): 4-5, 2014

Kongunadu Arts and Science College, Coimbatore

\title{
TEACHING LANGUAGE THROUGH TECHNOLOGY
}

\author{
Malathy, P*. \\ Department of English, Chikkaiah Naicker College, Erode. \\ *E.mail: malathykasc@gmail.com
}

\begin{abstract}
Teaching is demanding, exciting and gratifying. Students arrive in the classroom to learn and the task of the teacher becomes easier. Maintaining motivation then becomes the main objective. Brian O'Connell says "Without motivation, learning doesn't take place." Before teaching a class, it is essential to prepare and collect enough materials to cover the allocated teaching time. Teaching materials are used to promote learning, to maintain interest, to add variety to the lesson and to relate one subject to other subjects. There is a vast range of materials for teachers to use, although some are more readily available in certain countries than in others. Teachers always need more and more materials to keep up to date, and to renew worn items. It is useful to be aware of the applications of Modern Technology in the classroom although it is not readily available in many colleges or not available at all. Students enjoy variety in classroom and welcome the introduction of any form of film and screen presentations. The novelty factor immediately gains the full attention of the individual. And a highly professional studio production almost guarantees interest that will be maintained throughout the screening. Thus teaching through Technologies becomes a pleasurable experience for the students to learn. Modern appliances like Computers, Projectors, CD Player can be used in teaching. But all kind of Technologies still need the presence of a teacher, his smile, his heart and his motivation. The aim must be to produce a new generation full of humanity and life and not Computer - like students.
\end{abstract}

Keywords: Teaching language, Modern technology.

A Teacher's aim is to have the satisfaction of doing a good job, of creating learning situations for the maximum benefit of the students. To succeed in teaching, a teacher must strive to hold the attention of the students and make the class interesting. Teaching materials promote learning, maintain interest, add variety to the lesson and relate one subject to the other subjects. Hence it is essential for teachers to prepare and collect enough materials to teach. It is always a wise precaution to have extra material in classroom. There is a vast range of materials readily available for teachers to use.

Introducing materials in classroom enhance teaching and help to keep the students interest alive. Sitting and listening to a lecture becomes boring and the teacher has to strive for variety in teaching methods and materials. It is useful to be aware of the applications of modern technology in the classroom. During the second half of the twentieth century, modern technology was used to support language and learning. Technological devices are useful to teachers who wish to bring sounds and sights into the class room. Students enjoy variety within the classroom and welcome the introduction of any film and screen presentation. The novelty factor immediately gains the entire attention of the individual and a highly professional studio production almost guarantees interest that will be maintained throughout the screening. The students learn interestingly during this pleasurable experience and sufficient time must be allowed to the students to have discussion after screening or home assignments can be given based on it. Catalogues are available in libraries enumerating a list of educational films and cassettes available

for the students. Hence it is the task of a teacher to update her knowledge and expertise by a wide reading of the latest developments in teaching.

Adequate facilities like good classrooms, audio-video aids, congenial atmosphere etc go a long way in making the teaching purposeful and interesting. A lot of high quality audio materials are available for learners. They bring authentic voices into the classroom and make the learner to listen repeatedly to the most appropriate forms of spoken language. Video display provides visual support, variety and entertainment. Videos stimulate learner participation in role play and discussion. The most versatile and the most powerful educational aid and material is Computer, which offers sizeable contribution to language teaching. Computer is a powerful tool to store, transmit, present, retrieve and sort large amount of information in a non-linear way. Computer- based education is usually divided into Computer -Assisted Instruction and Computer Managed Instruction. Computer-Assisted Instruction (CAI) generally emphasis the complementary role of a computer in the teaching or learning process, even if computers are employed to provide instruction 
directly to learners. In early 1960s, large mainframe computers were used by a small number of University Language educators. But in the mid -tolate 1980s, an increasing number of language teachers became computer literate and started using computers while planning and carrying out their teaching. Power point presentation and other computer programs improve teacher's presentation of materials to the class.

The integration of information technology in teaching is a central matter in ensuring quality education. There are two important reasons for integrating information technology in teaching. Pupils must have familiarity with the use of information technology, since all jobs in the society of the future will be dependent on it and information technology must be used in teaching in order to improve its quality and make it more effective. Technology has become an important component in the current age. Every day the introduction of some new gadget and software make lives easier and improves the technology and software that already exists. Technology is playing an important role in education. As technology, advances it is used to benefit students of all ages in the learning process. Technology in classroom helps students absorb the material. Projection screen linked to computers allows students to see their notes instead of simply listening to a teacher's lecture.

The use of technology changes teaching in several ways. Technology makes teachers to be more creative in customizing their own material power. Students accept using technology for granted and the teachers must be expert in the use of technology to get students involved in the process of learning. Technology makes teaching easier and better. But it must be remembered that the new technologies will become old tomorrow and new things will come to life to bury the tools of today. However all technologies and tools will be appreciated as long as they satisfy the students thirst for knowledge .Most teachers generally feel that the introduction of technology may result in the loss of control, but, it must be remembered that the technological tools are not monsters and that a resourceful teacher can never be replaced.

There is no hard and fast rule as the right way to teach and this is a kind of blessing. But the day such a thing is discovered, will be the day that teaching becomes very dull. Teaching the student is a challenge and teachers seek and strive for innovative ways enabling learning more effective. This search for improvement makes teaching alive. It is not a matter how successful a course has been, but with happy students and good results a teacher should be looking ahead and considerable possible changes has to be made to the next course. While teaching a course, ideas often occur that perhaps next time a different approach may be followed. Perhaps there may be something discussed with colleagues or at conferences or read, that suggests some new ideas of teaching a course. An open mind, willingness to change when the need for change is obvious, will keep the teachers up to date and in the mainstream of teaching techniques.

Students remember an outstanding teacher from their own school days. Students who become teachers may be impressed by a particular teacher whom they observe in the course of their training. But in teaching one should be always be oneself. No book can totally prepare one for teaching. One has to find one's own way in teaching. It is a search for one's own salvation. Systems and ideas can only help teachers. Buddha said "Be a light unto yourself". (Krishnaswamy 342). The search is a never ending process in the evolution of a teacher.

A Teacher has to know her materials well, to put them to good use. A knowledge about the good set of materials is essential. Equally essential is the studied view of how to draw upon sources other than prescribed materials and how to relate them effectively to the topic addressed at a particular stage. It is smart to look for ways that will improve the ability of the teachers to teach but it's hard to see a machine that replaces the role of the teacher. Teaching is a human experience. Modern appliances like Computers, Projectors, CD player can be used in teaching. But all kind of Technologies still need the presence of a teacher, his smile, his heart and his motivation. The aim must be to produce a new generation full of humanity and life and not computer - like students.

\section{REFERENCES}

Coombs, Bryan. (1995) Successful Teaching. Botswana: Heinemann Educational Publishers.

Krishnaswamy. N, and Lalitha Krishnaswamy, (2003). Teaching English. Approaches, Methods, and Techniques. Chennai: Macmillan India Press.

Kumar, Krishna (1992). What is Worth Teaching? New Delhi: Orient Longman Limited.

Nagaraj, Geeta, (1996). English Language Teaching: Approaches, Methods, Techniques. Calcutta: Orient Longman Limited. 